\title{
CAUSALITY BETWEEN ENERGY CONSUMPTION AND ECONOMIC GROWTH IN THE V4 COUNTRIES
}

\author{
Radmila KRKOŠKOVÁ@i * \\ Department of Informatics and Mathematics, School of Business Administration in Karviná, \\ Silesian University in Opava, Karviná, Czech Republic
}

Received 13 March 2020; accepted 07 February 2021

\begin{abstract}
Energy plays an important role in economic development. This paper deals with the long-run relationship between energy consumption and real GDP for V4 countries from 2005 to 2019. The analysis was based on the unit root tests, co-integration tests, and causality tests. There are two questions. The first question is if energy consumption the stimulus to GDP, resp. energy consumption causes GDP. And the second question is if GDP the stimulus for energy consumption, resp. GDP causes consumption of energy. Energy consumption has an essential role in the economy on both the demand and the supply. It means that there should be a causal relationship from energy consumption to GDP as well as vice versa. Given that in the long run the energy consumption Granger causes the GDP in Slovakia, Hungary, and the Czech Republic, it means that energy consumption could cause economic growth in these countries. The only country where no significant relationship between energy consumption and the GDP has been demonstrated in Poland.
\end{abstract}

Keywords: ADF test, causality, energy, GDP, VECM, Visegrad Group.

JEL Classification: C22, Q43, Q48.

\section{Introduction}

The Visegrad Declaration (1991) describes the goals of these countries: the Czech Republic, Slovakia, Hungary and Poland. One of the goals is cooperation for linking energy interests. And this is reason why the countries of V4 were selected for analysis. The paper could confirm the relationship between the energy consumption and the economic growth in V4.

Higher energy efficiency in the European Union is statistically significantly associated with higher economic development. However, the positive effect of active measures to increase energy efficiency is a hypothesis based only on theoretical assumptions. Theoretical regulations are based on three main assumptions. Energy savings should lead to the release of funds for other economic activities. The long-term reduction of negative externalities

\footnotetext{
${ }^{\star}$ Corresponding author. E-mail: krkoskova@opf.slu.cz
} 
(market, foreign security, health, social and environmental) associated with energy overconsumption, especially from non-renewable resources, leads to a further increase in the expected positive impacts. However, these assumptions are hypothetical and have not been comprehensively modelled on the economies of the V4 countries.

The Visegrad Declaration (1991) mentions first efforts for energy cooperation as well as efforts to secure supplies from sources other than Russia. The Bratislava Summit discussed the issue of cooperation in the diversification of energy supplies in 1999, which was another step towards mutual cooperation in this area. The breakthrough occurred after the gas crises in 2006 and 2009, which hit the V4 countries. Due to the diversity of V4 energy mixes, it was difficult to find a joint strategy that would suit all V4 countries. The V4 countries also focus on nuclear cooperation and research and development of clean coal technologies. V4 cooperation and joint practices to balance the energy mix contribute to the EU energy policy. This cooperation also helps to bridge the energy deficit that occurs in coal, oil, natural gas, nuclear energy and renewable resources (European Commission, 2017).

It is natural that the dependence of the GDP and the energy consumption is not the same in all V4 countries. The article contains the following sections: a review of the literature, the econometric methods used, the economic development of V4 countries from the perspective of basic macroeconomic variables and the energy policy, and a model for each country.

\section{Literature review}

The literature review focuses primarily on articles that are oriented to the analysis of factors that affect or may affect energy consumption. Most of the articles focus on only a few factors (one to three) that are examined in relation to the amount of electricity consumption or total energy consumption. A large number of articles are focused on the relationship between total energy consumption and gross domestic production. This relation is explored in the article by Kose et al. (2013), which describes, among other things, the use of electricity consumption data to expose the so-called grey economy. This article also mentions the fact that especially western countries try to reduce this strong relationship of both indicators.

Faisal et al. (2016) argue that the relationship between GDP and energy consumption depends on a specific country, its composition of industry, etc. This means that there is not always a clear causality. The causality is tested for Russia in this article and the authors concluded that for Russia there is a mutual causality for GDP and electricity consumption.

Diversity in individual countries is also discussed in the article by Payne (2010), which discusses the causality of these factors and a literature review on the subject. The article focuses on a larger number of countries and also confirms that the causality between GDP and electricity consumption varies across countries.

Ozturk et al. (2010) divided countries into low- or middle-income groups. The GDP and electricity consumption were interconnected and causality was tested in both groups. The conclusion of the article is that the causality of low-income countries is such that GDP affects the amount of energy consumption, and it is a mutual causality in middle-income countries.

Authors Li et al. (2019) in their article point out that economic growth and the energy industry are interrelated. In China, the demand for energy is increasing as a result of improv- 
ing people's living standards. Cointegration methods were used in the article. Authors proved that there is a long-term stable relationship between energy consumption and economic growth, and there is unidirectional causality from economic growth to energy consumption.

The paper (Shahid et al., 2014) describes the situation of energy consumption in Brazil in the period 1971-2010. The authors used the least squares method to analyse the data in this article. There is a positive relationship between energy consumption and economic progress in Brazil.

The purpose of the paper (Szép, 2014) is to contribute to this topic with an analysis of Granger causality between energy consumption and economic growth in East-Central Europe. In his article, the author states that in the Czech Republic, Hungary and Slovakia there is a dependence between energy consumption and GDP. In these countries, energy consumption can lead to economic growth.

The study (Tang \& Oztruk, 2016) analysis of the relationship between the studied variables (the energy consumption and the GDP) in Vietnam during the period 1971-2011. The authors use Solow's model. The existence of cointegration was proved between the variables. There is Grander's causality from energy consumption to economic growth.

The authors (Wiranata \& Muqorrobin, 2013) use a vector error correction model for analysis. The results show that the long-term relationship between energy consumption and GDP has not been demonstrated in Malaysia. The results therefore confirm that Malaysia's GDP does not depend on energy consumption and, conversely, that energy consumption is not a significant factor influencing GDP growth.

This study (Pao et al., 2014) also describes the situation regarding the relationship between energy consumption and GDP in Brazil in the period from 1980 to 2008. The results indicate the existence of a long-term relationship between variables. The VEC model revealed a unidirectional short-run causality from energy consumption to economic growth, but also bidirectional causality. This means that Brazil should increase investment in the energy industry, but also not waste energy.

Evidence from a panel of OECD countries is discussed by Apergis and Payne (2010). The effect of renewable energy consumption on economic growth (Evidence from top 38 countries) is described by Bhattacharya et al. (2016) and a case of South Asian is described by Nepal and Paija (2019). Situation in Brazil is analysed in the paper by Pao and Fu (2013). The relationship between climate and energy consumption in South Korea is analysed in the paper by Shin et al. (2019). The study (Soava et al., 2018) examines the causal relationship between economic growth and energy consumption using data for 28 countries of European Union during period from 1995 to 2015 . The results of this research suggest a positive impact of energy consumption on economic growth, and there were confirmed bidirectional or unidirectional Granger causalities between the two macroeconomic variables, for each of 28 countries. The following paper (Soava et al., 2020) investigates relations between income inequality, economic growth and poverty threshold (EU countries panels). The article (Saad $\&$ Taleb, 2018) analyses and compares the short-run and long-run relationship between renewable energy consumption and economic growth in 12 European Union countries during period from 1990 to 2014 . The results show the presence of unidirectional causality running from economic growth to renewable energy consumption in the short run. In the long run, 
there exist a bidirectional causal relationship between the variables. Yildirim et al. (2012) analysis energy consumption in the USA. Energy consumption and economic growth in 67 countries is describes in full (Tugcu et al., 2012) and for the case Saudi Arabia it is describes in full (Wada, 2017). The authors Koç and Bahtiyar (2017) performed an analysis for the following countries: Turkey, South Africa, India, Indonesia and Brazil for the period 1971-2013. The study states that changes in economic growth have a positive effect on energy consumption. The authors Olopade et al. (2020) look at the relationship between technology, human capital and economic growth in Nigeria. According to Ozcicek and Agpak (2017), consumption energy is dependent on socioeconomic factors such as education, demographic qualifications, and energy. Authors Ozcan and Ozturk (2019) describe renewable energy consumption and economic growth relationship for 17 emerging countries examined. The neutrality hypothesis does hold for all of the countries except for Poland. The authors Zafar et al. (2019) divide energy, i.e. non-renewable and renewable energy consumption, and investigate its effect on economic growth. The results show the important role of energy (renewable and non-renewable) consumption in economic growth. This paper examines Asia-Pacific Economic Cooperation (APEC) countries during the period of 1990-2015.

Weather conditions are generally another factor to be studied. Most often it is the temperature where electricity (or energy in general) is consumed for heating at lower temperatures and for cooling (air conditioning) at higher temperatures.

The article (Bašta \& Helman, 2013) is very interesting, because the authors proceeded to the analysis of energy consumption depending on the outdoor temperature and the length of sunlight. The research was conducted in Prague. The results show that electricity consumption depends on the length of sunlight, which is not a surprising result. The interconnection of outdoor temperature with electricity consumption is dealt with in the article by Pampuri et al. (2016), which examines the impact of air conditioning in buildings on electricity consumption, specifically in the Canton Ticino area in Switzerland.

Authors (Popescu et al., 2019) have used the VEC model to determine the interrelationships between GDP, sustainable development and energy consumption. The research was conducted in Romania and the results confirm a proactive economic policy.

Germany is the largest economy in Europe and the analysis between energy consumption and economic growth is described by authors Rafindadi and Ozturk (2017). The causality analysis revealed the existence of feedback effect between renewable energy consumption and economic growth. It is bidirectional relationship.

The paper by Mutascu (2016) has investigated the causality between energy consumption and economic growth (during the period 1970-2012) in the countries of the Group of Seven (G7). The results show a bi-directional causality between energy consumption and GDP in Canada, Japan, and the United States. GDP causes energy consumption in France and Germany, while no causality is found for Italy and the United Kingdom.

The direction between the energy consumption (EC) and the GDP can be of 4 kinds: $E C \rightarrow G D P(E C$ causes GDP), GDP $\rightarrow E C$ (GDP causes $E C$ ), $E C \leftrightarrow G D P$ (bi-directional causality), EC no $\leftrightarrow G D P$ (no causality exists). The Table 1 shows some studies which investigate the connection between energy consumption and economic growth using by panel data analysis. 
Table 1. Studies which analyse the relationship between EC and GDP (source: choosing of the literature developed by the author)

\begin{tabular}{|c|c|c|c|c|}
\hline Author/s & Period & Country & Methods & Results \\
\hline $\begin{array}{l}\text { Furuoka } \\
(2017)\end{array}$ & $1992-2011$ & $\begin{array}{l}\text { Baltic } \\
\text { countries }\end{array}$ & $\begin{array}{l}\text { Panel cointegration test, } \\
\text { Panel causality test }\end{array}$ & $G D P \rightarrow E C$ \\
\hline $\begin{array}{l}\text { Koçak and } \\
\text { Şarkgüneşi } \\
(2017)\end{array}$ & $1990-2012$ & $\begin{array}{l}9 \text { Black Sea } \\
\text { and Balkan } \\
\text { countries }\end{array}$ & $\begin{array}{l}\text { Heterogeneous panel } \\
\text { causality }\end{array}$ & $\begin{array}{c}E C \rightarrow G D P: \text { Bulgaria, Greece, } \\
\text { Macedonia, Russia, Ukraine } \\
E C \leftrightarrow G D P: \text { Albania, Georgia, } \\
\text { Romania } \\
E C \text { no } \leftrightarrow \text { GDP: Turkey }\end{array}$ \\
\hline $\begin{array}{l}\text { Maji, } \\
\text { Sulaiman, and } \\
\text { Abdul-Rahim } \\
\text { (2019) }\end{array}$ & $1995-2014$ & $\begin{array}{l}15 \text { West } \\
\text { African } \\
\text { countries }\end{array}$ & $\begin{array}{l}\text { Panel dynamic ordinary } \\
\text { least squares (DOLS) }\end{array}$ & $E C$ no $\leftrightarrow G D P$ \\
\hline $\begin{array}{l}\text { Alvarado } \\
\text { et al. (2019) }\end{array}$ & $1972-2014$ & $\begin{array}{l}19 \text { countries } \\
\text { of Latin } \\
\text { America }\end{array}$ & $\begin{array}{l}\text { Pedroni and Westerlund } \\
\text { cointegration } \\
\text { techniques, Dumitrescu } \\
\text { and Hurlin causality test }\end{array}$ & $E C \leftrightarrow G D P$ \\
\hline $\begin{array}{l}\text { Rahman and } \\
\text { Velayutham } \\
(2020)\end{array}$ & 1990-2014 & $\begin{array}{l}5 \text { South } \\
\text { Asian } \\
\text { countries }\end{array}$ & $\begin{array}{l}\text { Pedroni and Kao tests, } \\
\text { FMOLS and DOLS } \\
\text { estimation techniques, } \\
\text { Dumitrescue-Hurlin }\end{array}$ & $G D P \rightarrow E C$ \\
\hline
\end{tabular}

Table 1 shows diverse results during different periods. The results of this article: bi-directional causality does not confirm for any country of V4, and causality energy consumption causes GDP was confirmed for the Czech Republic, Slovakia and, Hungary.

\section{Method}

In the article is performed the individual analysis of each country. We examine the long-run relationship in a function $G D P=f(E C)$; where $G D P=\ln$ of real Gross Domestic Product; $E C=\ln$ of Energy Consumption. The methods are described in the articles Hendry and Juselius $(2000,2001)$.

The first step is to determine if the variables are stationary. The augmented Dickey-Fuller (ADF) test will be used to decide on the stationarity of variables. Engle and Granger (1987), Enders (2014) argue that most time series in macroeconomics are non-stationary or integrated with order I (1).

If all the variables are stationary, then vector autoregressive (VAR) model can be used. If the variables of type I (1) we use the error correction model (VECM) and test the cointegration and determine the Granger causality connections.

The general form of the VECM model is:

$$
\Delta y_{t}=\beta_{0}+\beta_{1} \Delta x_{t}+\gamma_{1} x_{t-1}+\gamma_{2} y_{t-1}+u_{t},
$$

where $x_{t}, y_{t}$ are economic variables, $u_{t}$ is the residual variable. 
In our case, two variables will be used and the lag lengths is equal to one. The VAR model can be written as follows:

$$
\begin{aligned}
& X_{t}=\alpha_{0}+\alpha_{1} X_{t-1}+\alpha_{2} Y_{t-1} \\
& Y_{t}=\beta_{0}+\beta_{1} Y_{t-1}+\beta_{2} X_{t-1}
\end{aligned}
$$

\section{Economic development and the energy policy of V4 countries}

The members of the Visegrad Group are: the Czech Republic, Slovakia, Poland and Hungary. Quarterly data for the period from 2005/Q1 to 2019/Q3 were used for the analysis.

\subsection{Gross domestic product}

The growth of real gross domestic product is the first macroeconomic variable that compares the performance of economies. Diagram 1 shows the development of real GDP growth in the V4 countries between 2005 and 2019. The growth of all economies is evident after accession to the EU. Countries became more open for abroad, more transparent and benefited from EU funds. Slovakia achieved the highest real GDP growth. On the contrary, there was a deep decline in Hungary since 2006, mainly due to the high state budget deficit. These problems were fully manifested during the economic crisis, when there was a problem of debt repayment, and the entire Hungarian economy was in a deep recession. All V4 countries experienced a noticeable slump, with the exception of Poland. Poland was the only one to remain in the black, mainly due to greater self-sufficiency, and Poland was not so dependent on exports. Gradually, the V4 countries began to recover from the crisis and there was a slight increase after the recession, as shown in Figure 1.

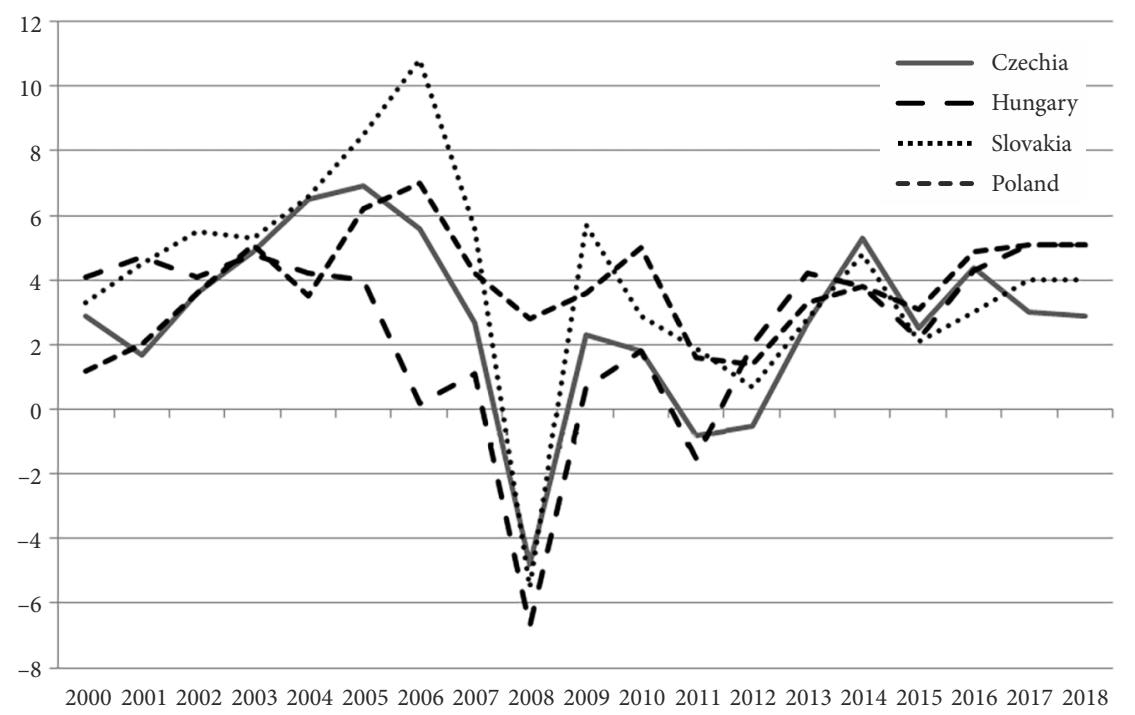

Figure 1. Development of real GDP growth of V4 countries for the period 2000-2018 (v \%) (source: Eurostat, 2018a, own calculations) 


\subsection{The energy policy}

The Czech Republic has approved a national energy policy (SEP), the aim of which is to reduce energy consumption and improve the energy intensity of the economy. The aim of this project is to build a competitive and sustainable energy sector. The results also show that the Czech Republic is performing well in the renewable energy sector. One of the main objectives of the SEP is the development of nuclear energy. The SEP also establishes key targets for energy security, emissions, energy savings, electricity generation, and affordability. This review also provides recommendations for further policy improvements that are intended to help guide the country towards a more secure and sustainable energy future (International Energy Agency [IEA], 2018a).

The Slovak Republic has made significant progress in the area of energy policy. These are, in particular, the areas of energy security and competitiveness. The review includes incorporating ambitious targets for 2030 on energy security, $\mathrm{CO}_{2}$ emissions, and energy markets; continuing to decarbonise the heating sector; developing a clear and transparent program for eliminating administratively determined end-user prices of electricity and natural gas; and taking further measures to limit energy-related $\mathrm{CO}_{2}$ emissions in the transport sector, in particular (IEA, 2018b).

Poland's energy strategy addresses the issue of coal, as the coal industry predominates in the Polish energy sector. The aim is to reduce sources of greenhouse gas emissions, increase energy efficiency, ensure energy security. Poland has achieved good results in the field of renewable energy. Nuclear energy could play a significant role in the country's energy supply (IEA, 2018c).

In Hungary, the topic of energy policy elaborated in the National Energy Strategy to 2030. As in other countries, and Hungary are important for the following areas: safety, sustainability, competitiveness and reduce emissions. Hungary has already invested in infrastructure and other investments can be expected in the field of nuclear energy (IEA, 2018d).

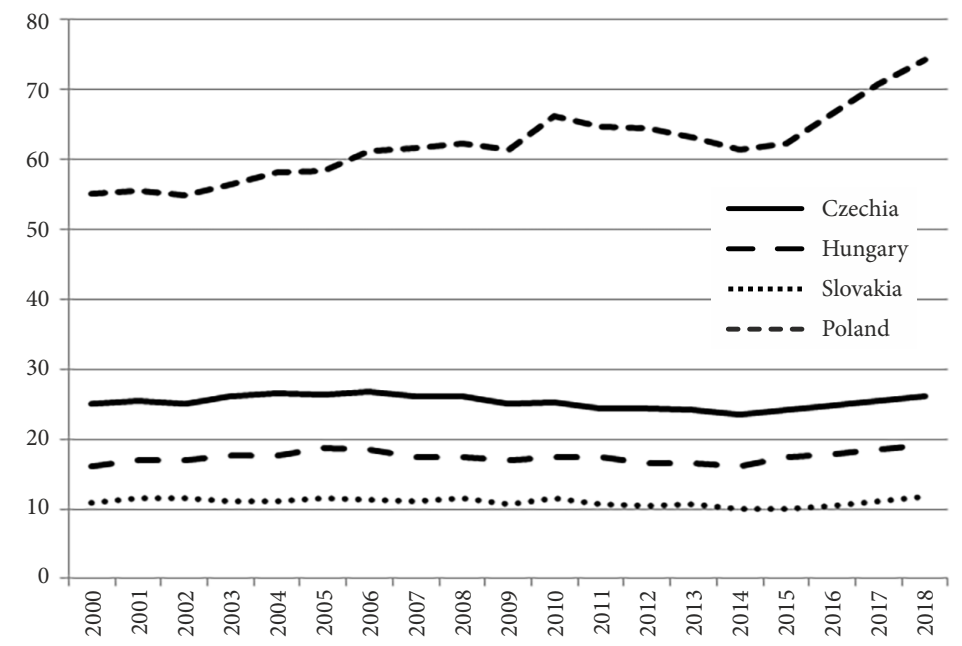

Figure 2. Final Energy Consumption V4 countries for the period 2000-2018 (million tonnes of oil equivalent) (source: Eurostat, 2018b, own calculations) 


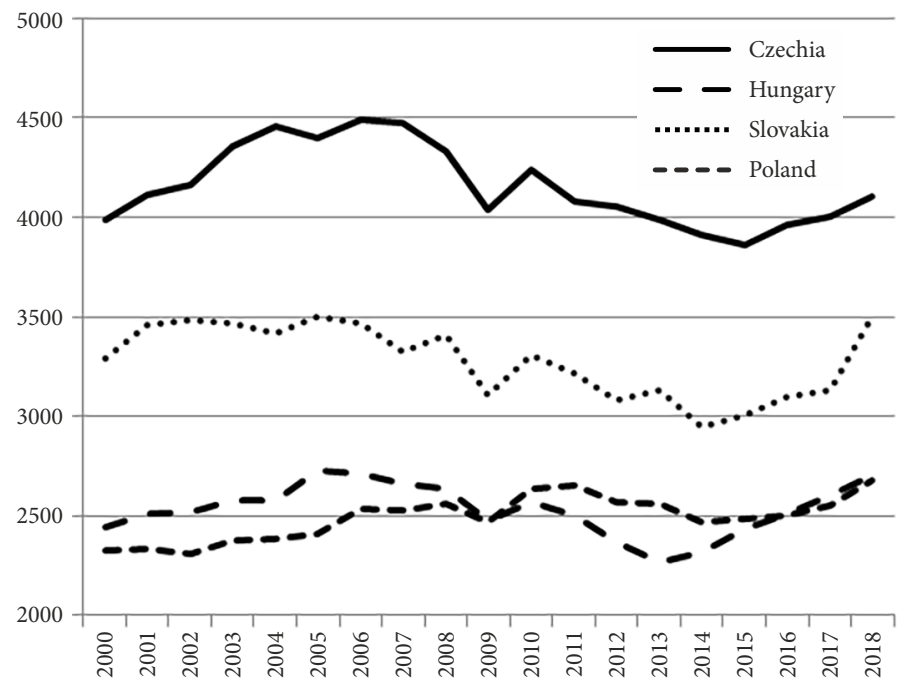

Figure 3. Energy Consumption V4 countries for the period 2000-2018 per capita (kg of oil equivalent) (source: Google, 2020, own calculations)

Another possible indicator for assessing the country's energy consumption is the final energy consumption per capita, which is shown in the following Figure 3. In the Czech Republic, the final energy consumption per capita is the highest. Most economically developed countries (with high GDP per capita) have a higher indicator. However, for example, the United Kingdom has this value just below the EU average and France has lower values than the Czech Republic. Energy consumption per capita in the Czech Republic and Slovakia is higher than the EU average and in Hungary and Poland, there is lower (Europa.eu, 2020a). According to energy intensity of the economy in 2017: the Czech Republic $=152$, Hungary $=$ 134 , Poland $=131$, Slovakia $=138$ [kg of oil equivalent per 1000 EUR]. Energy consumption in the Czech Republic is extremely high, and the potential for energy savings is higher than in other neighboring countries. Only Bulgaria and Estonia have higher energy intensity. The countries of the former Eastern bloc generally have higher energy intensity than the countries of Western Europe, (Europa.eu, 2020b). This fact is to a large extent also influenced by the greater industrial orientation of the past.

\section{Relationships between economic development and energy consumption - co-integration analysis}

The data used have the character of quarterly time series in the period from 2000Q1 to 2019Q3. Quarterly time series data in the period from 2000Q10 to 2019Q3 were used for the calculations. All values were considered in logarithmic terms (EViews 12 (IHS Global Inc., 2020)). Data were obtained from the Eurostat database.

Variables used in our research are: GDP and the energy consumption. Variables CZ_GDP, $S K \_G D P, H U \_G D P$ and $P L \_G D P$ are listed in million units of national currency and consid- 
ered in logarithmic terms. Variables $C Z \_E C, S K \_E C, H U \_E C$ and $P L \_E C$ are listed in million tonnes of oil equivalent (TOE) and considered in logarithmic terms.

In the article the individual analysis of each country (chapters 4.1-4.4) are performed.

The variables (CR_GDP, CR_EC), ( $\left.P L \_G D P, P L \_E C\right)$ are type of $\mathrm{I}(1)$ as the Table 2 shows. Therefore, the long-run co-integration relationships may exist between these time series. Using the Johansen's method, it was confirmed the existence of 1 co-integration relationship for $\operatorname{VECM}(1)$ in the case of the Czech Republic. In the case of Poland the variables are not co-integrated.

The variables (SK_GDP, SK_EC), (HU_GDP, HU_EC) are zero-order integrated. In the case of Slovakia and Hungary the energy consumption use Granger causes the GDP. The Granger causality for Poland has not been proven.

If the variables are not co-integrated we can use the VAR model to determine the directions of causality. The direction between the energy consumption (EC) and the GDP can be of 4 kinds:

1) EC Granger causes GDP; growth hypothesis. Programs aimed at reducing energy consumption may limit economic growth. Increasing energy consumption can lead to economic growth. Energy is a necessary production factor, similar to labour or capital.

2) GDP Granger causes EC; conservation hypothesis. Policies aimed at reducing energy consumption may be implemented with little or no impact on economic growth.

3) EC Granger causes GDP and GDP Granger causes EC; feedback hypothesis. It is an interconnection between GDP and energy consumption.

4) No Granger-causality exists; neutrality hypothesis. There is no significant relationship between energy consumption and GDP or economic growth. Thus, energy policy, whether aimed at increasing or reducing energy consumption, will not affect economic growth and vice versa.

Cases 1) and 2) represent uni-directional causality and case 3) represents bi-directional causality.

The first step is testing the stationarity of variables included in the model or their first differences. Table 2 shows the test results for all variables of all countries. The Dickey-Fuller test (ADF) was used to test the stationarity. The column Result means the result of testing: $\mathrm{N}=$ non-stationary variable, $\mathrm{S}=$ stationary variable.

Table 2. ADF test (source: own calculations, EViews)

\begin{tabular}{|l|c|c|c|c|c|c|c|c|c|}
\hline variable & $\mathrm{n} / \mathrm{c} / \mathrm{c}+\mathrm{t}$ & T-stat & Prob. & Result & variable & $\mathrm{n} / \mathrm{c} / \mathrm{c}+\mathrm{t}$ & T-stat & Prob. & Result \\
\hline$C R \_G D P$ & $\mathrm{c}$ & -0.468 & 0.891 & $\mathrm{~N}$ & $\mathrm{D}\left(C R \_G D P\right)$ & $\mathrm{c}$ & -4.886 & 0.001 & $\mathrm{~S}$ \\
\hline$C R \_E C$ & $\mathrm{c}$ & -1.238 & 0.653 & $\mathrm{~N}$ & $\mathrm{D}\left(C R \_E C\right)$ & $\mathrm{c}$ & -4.495 & 0.001 & $\mathrm{~S}$ \\
\hline$S K \_G D P$ & $\mathrm{c}+\mathrm{t}$ & -5.215 & 0.001 & $\mathrm{~S}$ & & & & & \\
\hline$S K \_E C$ & $\mathrm{n}$ & -4.656 & 0.027 & $\mathrm{~S}$ & & & & & \\
\hline$H U \_G D P$ & $\mathrm{c}$ & -4.047 & 0.035 & $\mathrm{~S}$ & & & & & \\
\hline$H U \_E C$ & $\mathrm{c}+\mathrm{t}$ & -4.971 & 0.000 & $\mathrm{~S}$ & & & & & \\
\hline$P L \_G D P$ & $\mathrm{c}+\mathrm{t}$ & -1.612 & 0.778 & $\mathrm{~N}$ & $\mathrm{D}\left(P L \_G D P\right)$ & $\mathrm{c}+\mathrm{t}$ & -3.127 & 0.032 & $\mathrm{~S}$ \\
\hline$P L \_E C$ & $\mathrm{n}$ & 1.724 & 0.978 & $\mathrm{~N}$ & $\mathrm{D}\left(P L \_E C\right)$ & $\mathrm{c}$ & -3.387 & 0.014 & $\mathrm{~S}$ \\
\hline
\end{tabular}




\subsection{The Czech Republic}

Existence of one long-term bond can be specified by a co-integration equation:

$$
E Q \_C R=C R \_G D P_{t}+28.38 C R \_E C_{t} .
$$

We can see that the co-integration vector is $(1.00 ; 28.38)$. This means that a $1 \%$ decrease in $C R \_E C$ will cause an increase in CR_GDP by $28.38 \%$. This means that reducing energy consumption leads to faster GDP growth. This is the motivation for so-called "austerity programs".

Table 3 shows that the correction term is statistically significant and the model explains the return to long-term equilibrium. Regarding regression coefficients, it can be argued that GDP is negatively related to the energy consumption, with quarterly delays.

Table 3. Estimates VECM(1) (source: own calculations, EViews)

\begin{tabular}{|c|c|c|}
\hline Error Correction: & $\mathrm{D}\left(C R \_G D P\right)$ & $\mathrm{D}\left(C R \_E C\right)$ \\
\hline CointEq1 & $-0.010663^{* *}$ & $-0.013747^{* * *}$ \\
& $(0.00487)$ & $(0.00414)$ \\
& {$[-2.18754]$} & {$[-3.31919]$} \\
\hline $\mathrm{D}\left(C R \_G D P(-1)\right)$ & -0.078228 & 0.190736 \\
& $(0.13026)$ & $(0.11068)$ \\
& {$[-0.60056]$} & {$[1.72331]$} \\
\hline $\mathrm{D}\left(C R \_E C(-1)\right)$ & $-0.728761^{* * *}$ & $-0.413017^{* * *}$ \\
& $(0.20595)$ & $(0.17499)$ \\
& {$[-3.53856]$} & -0.000691 \\
& $0.013338^{* * *}$ & $(0.00466)$ \\
& $(0.00548)$ & {$[-0.14831]$} \\
\hline C & {$[2.43356]$} & 0.319 \\
\hline
\end{tabular}

Note: Statistical significance at the 0.01 level $\left({ }^{* *}\right)$, at the 0.05 level $\left({ }^{* *}\right)$, at the 0.1 level $\left({ }^{*}\right)$. Standard errors in ( ) \& t-statistics in [ ].

This part of article deals with the testing of short-term relationships (Granger causality). The Granger causality test is a statistical hypothesis test for determining whether one time series is useful in forecasting another (Granger, 1969). Rather than testing whether $Y$ causes $X$, the Granger causality tests whether $Y$ forecasts $X$. It is necessary to work with the stationary time series. Due to the fact that these are quarterly data, Granger causality is tested at the 1, 2, 3, 4 delay. The similar procedure is given in Krkošková (2020). We consider the 5\% significance level. The results of the series 1 delay test are shown in Table 4.

The Table 4 shows that the energy consumption use Granger causes the GDP. It means that the energy conservation policies can retard the growth rate of GDP. 
Table 4. Pairwise Granger causality tests (lag 1) (source: own calculations, EViews)

\begin{tabular}{|l|c|c|}
\hline \multicolumn{1}{|c|}{ Null Hypothesis: } & Statistic & Sign. \\
\hline $\mathrm{D}\left(C R \_G D P\right)$ does not Granger cause $\mathrm{D}\left(C R \_E C\right)$ & 2.57 & 0.145 \\
\hline $\mathrm{D}\left(C R \_E C\right)$ does not Granger cause $\mathrm{D}\left(C R \_G D P\right)$ & 4.14 & $\mathbf{0 . 0 7 1}$ \\
\hline
\end{tabular}

\subsection{Slovakia}

The variables (SK_GDP, SK_EC) are zero-order integrated, i.e. I(0). It shows Table 2.

The VAR models can be written as:

$$
\begin{aligned}
& S K \_E C=0.994+0.259 . S K \_E C(-1)-0.025 . S K \_G D P(-1), \\
& S K \_G D P=1.104-0.537 . S K \_E C(-1)+0.943 . S K \_G D P(-1) .
\end{aligned}
$$

The first equation shows that the dependent variable $E C$ is positively related to the rise in the $E C$ with quarterly delays, and negatively related to the rise in the GDP, with quarterly delays.

The Table 5 shows that the energy consumption use Granger causes the GDP. It means that the energy conservation policies can retard the growth rate of GDP.

Table 5. Pairwise Granger causality tests (lag 1) (source: own calculations, EViews)

\begin{tabular}{|l|c|c|}
\hline \multicolumn{1}{|c|}{ Null Hypothesis: } & Statistic & Sign. \\
\hline SK_GDP does not Granger cause $S K \_E C$ & 0.01 & 0.817 \\
\hline SK_EC does not Granger cause $S K \_G D P$ & 8.74 & $\mathbf{0 . 0 0 9}$ \\
\hline
\end{tabular}

\subsection{Hungary}

The variables (HU_GDP, HU_EC) are zero-order integrated, i.e. I(0). It shows Table 2.

The VAR models can be written as

$$
\begin{aligned}
& H U \_E C=0.338+0.421 . H U \_E C(-1)+0.033 \cdot H U \_G D P(-1), \\
& H U \_G D P=1.141-0.805 . H U \_E C(-1)+1.004 . H U \_G D P(-1) .
\end{aligned}
$$

The first equation shows that the dependent variable $E C$ is positively related to the rise in the GDP and positively related to the energy consumption, with quarterly delays.

The Table 6 shows that the energy consumption use Granger causes the GDP. It means that the energy conservation policies can retard the growth rate of GDP.

Table 6. Pairwise Granger causality tests (lag 1) (source: own calculations, EViews)

\begin{tabular}{|l|c|c|}
\hline \multicolumn{1}{|c|}{ Null Hypothesis: } & Statistic & Sign. \\
\hline$H U \_G D P$ does not Granger cause $H U \_E C$ & 1.58 & 0.245 \\
\hline$H U \_E C$ does not Granger cause $H U_{-} G D P$ & 10.51 & $\mathbf{0 . 0 0 2}$ \\
\hline
\end{tabular}




\subsection{Poland}

The variables ( $\left.P L \_G D P, P L \_E C\right)$ are first-order integrated, i.e. I(1). It has been calculated in the Table 2.

Because the time series are I(1) it can be calculated the co-integration test for Poland. The Table 7 shows these co-integration tests.

Table 7. Co-integration test (source: own calculations, EViews)

\begin{tabular}{|c|c|c|c|}
\hline Country & Engle-Granger test & Johansen co-integration test & Result. \\
\hline \multirow{2}{*}{$P L$} & $-1.749(0.577)$ & $4.952(0.793)$ & No co-integration \\
& $-0.536(0,894)$ & & \\
\hline
\end{tabular}

The series are not co-integrated and in the next step we determine causality directions with the VAR-model.

The VAR models can be written as:

$$
\begin{aligned}
& P L \_E C=0.108+0.631 . P L \_E C(-1)+0.071 . P L \_G D P(-1), \\
& P L \_G D P=1.521-0.346 . P L \_E C(-1)+1.035 . P L \_G D P(-1) .
\end{aligned}
$$

There are the same results as in the case of Hungary. We can say that the dependent variable $E C$ is positively related to the rise in the GDP and positively related to the energy consumption, with quarterly delays.

The Table 8 shows that in the case of Poland there is no connection found.

Table 8. Pairwise Granger causality tests (lag 1) (source: own calculations, EViews)

\begin{tabular}{|l|c|c|}
\hline \multicolumn{1}{|c|}{ Null Hypothesis: } & Statistic & Sign. \\
\hline $\mathrm{D}\left(P L_{-} G D P\right)$ does not Granger cause $\mathrm{D}\left(P P_{-} E C\right)$ & 0.006 & 0.983 \\
\hline $\mathrm{D}\left(P L_{-} E C\right)$ does not Granger cause $\mathrm{D}\left(P P_{-} G D P\right)$ & 1.51 & 0.356 \\
\hline
\end{tabular}

\subsection{Model assumptions, impulse response function, forecast error decomposition}

Model assumptions for all countries were met: null hypotheses concerning autocorrelation, heteroscedasticity normality were not rejected at the $5 \%$ significance level. The residual component meets the requirements. The Table 9 shows the overview of the results of Granger's causality. These results are important from the perspective of energy policies.

Table 9. Conclusion of the Granger causality tests (source: own calculations)

\begin{tabular}{|l|c|}
\hline \multicolumn{1}{|c|}{ Country } & Granger causality \\
\hline Czech Republic, Slovakia, Hungary & EC $\rightarrow$ GDP \\
\hline Poland & No causality \\
\hline
\end{tabular}

Table 9 shows that in the case of the Czech Republic, Slovakia and Hungary the energy use Granger causes GDP. In the case of Poland the causality has not been demonstrated. 
The decomposition of variance is eligible for testing variables and to certify the results which are shown in Table 9. Following graphs (Figure 4) in the first column show the function of the response to a positive exogenous shock in energy consumption. The course of the function is similar for the Czech Republic, Slovakia and Hungary. A positive exogenous unit shock in the EC will cause a decline in GDP by Q2 and then an increase by Q3. In the case of Poland, the function is declining. In the case of the positive exogenous shock response function in GDP, the graphs have a different course.

Table 10 shows the results for the Czech Republic. The results in the Table 10, to be more precise, in the 5th period, are interesting, because the shock in energy consumption affected $64.4 \%$ of the variance of the GDP forecast error. The table also shows that the shock in the economic growth affected $21.9 \%$ of the variance of the energy consumption forecast error.

Table 10. Results of decomposition of variance for the Czech Republic (source: own calculations, EViews)

\begin{tabular}{|c|c|c|c|c|c|c|c|}
\hline \multicolumn{4}{|c|}{ Variance Decomposition of CZ_EC } & \multicolumn{4}{c|}{ Variance Decomposition of CZ_GDP } \\
\hline Period & S.E. & CZ_EC & CZ_GDP & Period & S.E. & CZ_EC & CZ_GDP \\
\hline 1 & 0.0463 & 100.000 & 0.000 & 1 & 0.0393 & 60.560 & 39.439 \\
\hline 2 & 0.0539 & 77.649 & 22.350 & 2 & 0.0421 & 64.249 & 35.751 \\
\hline 3 & 0.0587 & 77.134 & 22.865 & 3 & 0.0435 & 64.108 & 35.891 \\
\hline 4 & 0.0642 & 76.533 & 23.466 & 4 & 0.0449 & 64.334 & 35.665 \\
\hline 5 & 0.0685 & 78.042 & $\mathbf{2 1 . 9 5 7}$ & 5 & 0.0453 & $\mathbf{6 4 . 4 3 8}$ & 35.561 \\
\hline 6 & 0.0727 & 72.984 & 27.015 & 6 & 0.0456 & 64.364 & 35.635 \\
\hline 7 & 0.0766 & 71.706 & 28.293 & 7 & 0.0457 & 64.315 & 35.684 \\
\hline 8 & 0.0803 & 70.618 & 29.381 & 8 & 0.0458 & 64.261 & 35.738 \\
\hline 9 & 0.0838 & 69.734 & 30.265 & 9 & 0.0459 & 64.207 & 35.792 \\
\hline 10 & 0.0872 & 68.920 & 31.079 & 10 & 0.0459 & 64.164 & 35.835 \\
\hline
\end{tabular}

The results of Slovakia are in the Table 11 and these results are similar as results in the Table 10 . In the $10^{\text {th }}$ period, we can see, that the percussion in the energy consumption affected $66.6 \%$ of variance decomposition of the economic growth, otherwise it is $22.3 \%$

Table 11. Results of decomposition of variance for Slovakia (source: own calculations, EViews)

\begin{tabular}{|c|c|c|c|c|c|c|c|}
\hline \multicolumn{4}{|c|}{ Variance Decomposition of SK_EC } & \multicolumn{4}{c|}{ Variance Decomposition of SK_GDP } \\
\hline Period & S.E. & SK_EC & SK_GDP & Period & S.E. & SK_EC & SK_GDP \\
\hline 1 & 0.0459 & 100.000 & 0.000 & 1 & 0.0950 & 43.198 & 56.801 \\
\hline 2 & 0.0575 & 99.534 & 0.465 & 2 & 0.1281 & 44.379 & 55.620 \\
\hline 3 & 0.0636 & 88.563 & 11.436 & 3 & 0.1507 & 45.772 & 54.227 \\
\hline 4 & 0.0674 & 87.224 & 12.775 & 4 & 0.1680 & 47.423 & 52.576 \\
\hline 5 & 0.0700 & 85.662 & 14.337 & 5 & 0.1822 & 49.391 & 50.609 \\
\hline 6 & 0.0719 & 83.999 & 16.001 & 6 & 0.1941 & 51.742 & 48.257 \\
\hline 7 & 0.0735 & 82.328 & 17.671 & 7 & 0.2043 & 54.559 & 45.441 \\
\hline 8 & 0.0748 & 80.711 & 19.288 & 8 & 0.2132 & 57.926 & 42.073 \\
\hline 9 & 0.0759 & 79.184 & 20.815 & 9 & 0.2210 & 61.925 & 38.074 \\
\hline 10 & 0.0770 & 77.766 & $\mathbf{2 2 . 2 3 3}$ & 10 & 0.2280 & $\mathbf{6 6 . 6 0 8}$ & 33.391 \\
\hline
\end{tabular}



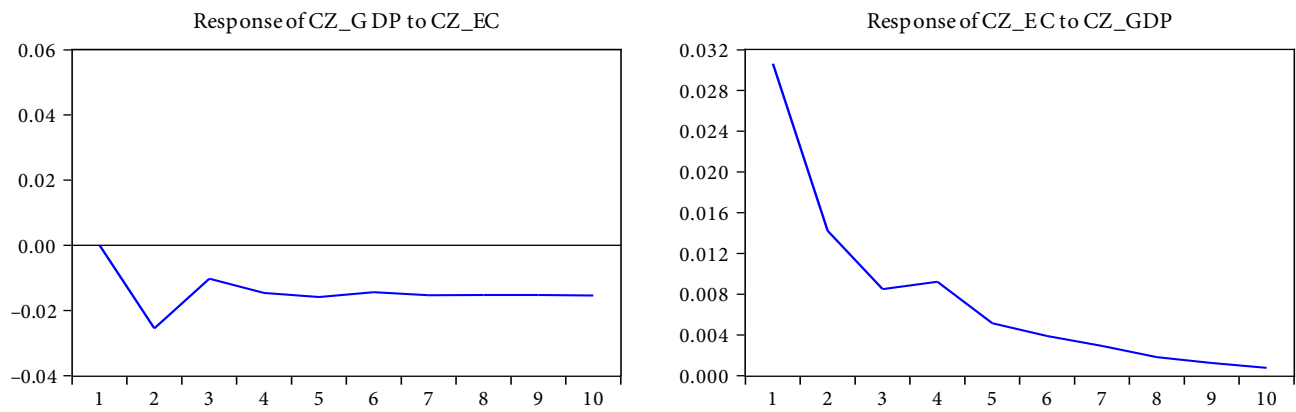

Response of SK_GDP to SK_EC

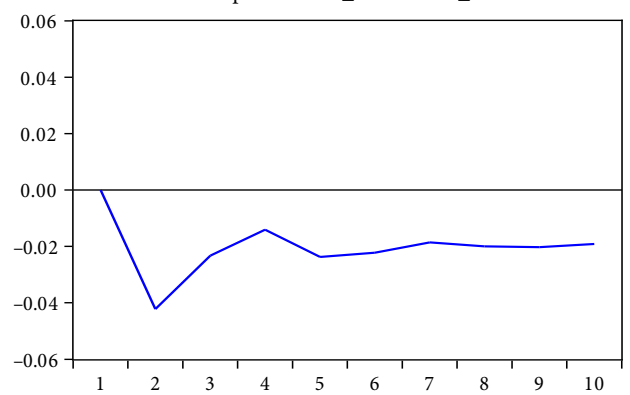

Response of SK_EC to SK_GDP

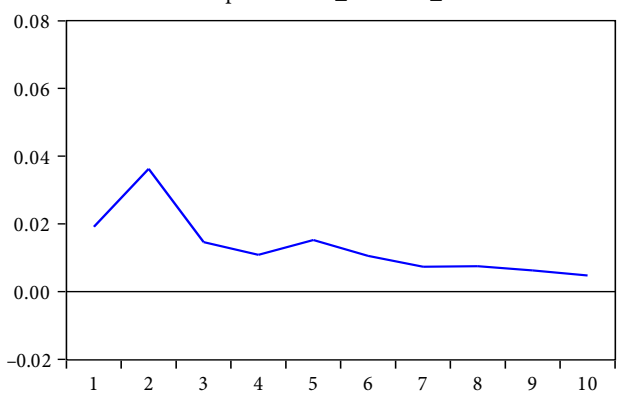

Response ofHU_GDP to HU_EC

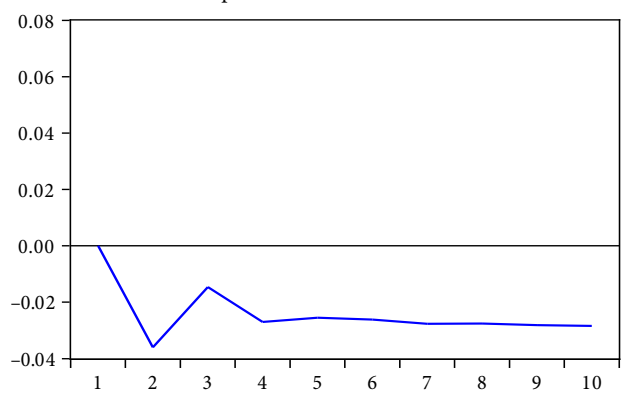

Response of HU_EC to HU_GDP

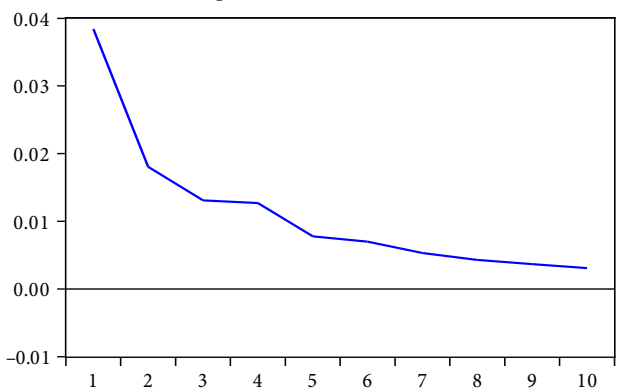

Response of PL_GDP to PL_EC

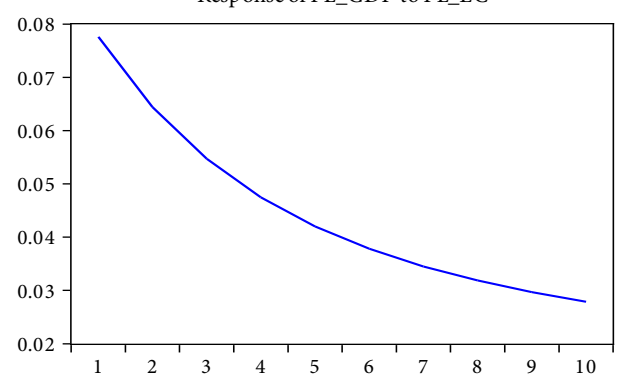

Response of PL_EC to PL_GDP

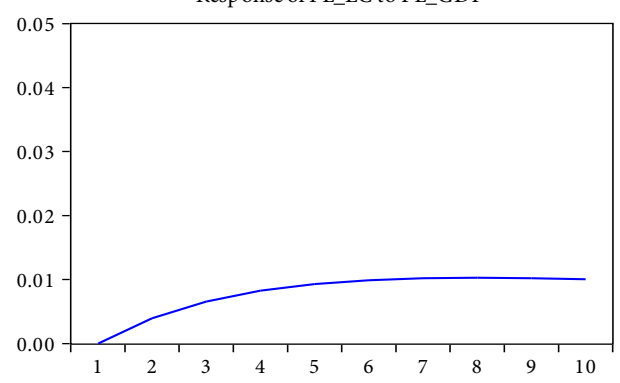

Figure 4. Response to Cholesky One S.D. Innovations, (source: own calculations, EViews) 
Table 12 shows the results for Hungary. The results in the $10^{\text {th }}$ period correspond to the inference that energy consumption affects the economic growth.

Table 12. Results of decomposition of variance for Hungary (source: own calculations, EViews)

\begin{tabular}{|c|c|c|c|c|c|c|c|}
\hline \multicolumn{4}{|c|}{ Variance Decomposition of HU_EC } & \multicolumn{4}{c|}{ Variance Decomposition of HU_GDP } \\
\hline Period & S.E. & HU_EC & HU_GDP & Period & S.E. & HU_EC & HU_GDP \\
\hline 1 & 0.0551 & 100.000 & 0.000 & 1 & 0.0892 & 15.186 & 84.813 \\
\hline 2 & 0.0607 & 99.876 & 0.123 & 2 & 0.1116 & 15.525 & 84.474 \\
\hline 3 & 0.0618 & 99.638 & 0.361 & 3 & 0.1284 & 15.961 & 84.038 \\
\hline 4 & 0.0620 & 99.346 & 0.653 & 4 & 0.1427 & 16.548 & 83.451 \\
\hline 5 & 0.0622 & 99.042 & 0.957 & 5 & 0.1551 & 17.383 & 82.616 \\
\hline 6 & 0.0623 & 98.748 & 1.251 & 6 & 0.1659 & 18.666 & 81.333 \\
\hline 7 & 0.0623 & 98.474 & 1.525 & 7 & 0.1752 & 20.839 & 79.160 \\
\hline 8 & 0.0624 & 98.223 & 1.776 & 8 & 0.1833 & 24.886 & 75.113 \\
\hline 9 & 0.0625 & 97.993 & 2.006 & 9 & 0.1904 & 32.854 & 67.145 \\
\hline 10 & 0.0626 & $\mathbf{9 7 . 7 8 5}$ & 2.214 & 10 & 0.1967 & $\mathbf{4 7 . 6 4 7}$ & 52.352 \\
\hline
\end{tabular}

Table 13 describes the results of Poland and we can see a weak causality direction.

Table 13. Results of decomposition of variance for Poland (source: own calculations, EViews)

\begin{tabular}{|c|c|c|c|c|c|c|c|}
\hline \multicolumn{4}{|c|}{ Variance Decomposition of PL_EC } & \multicolumn{4}{c|}{ Variance Decomposition of PL_GDP } \\
\hline Period & S.E. & PL_EC & PL_GDP & Period & S.E. & PL_EC & PL_GDP \\
\hline 1 & 0.0748 & 100.000 & 0.000 & 1 & 0.0479 & 7.698 & 92.301 \\
\hline 2 & 0.0772 & 99.979 & 0.020 & 2 & 0.0665 & 9.364 & 90.635 \\
\hline 3 & 0.0774 & 99.950 & 0.049 & 3 & 0.0829 & 15.722 & 84.277 \\
\hline 4 & 0.0774 & 99.921 & 0.079 & 4 & 0.0964 & 19.674 & 80.325 \\
\hline 5 & 0.0774 & 99.891 & 0.108 & 5 & 0.1075 & 12.065 & 77.934 \\
\hline 6 & 0.0775 & 99.865 & 0.134 & 6 & 0.1169 & 23.612 & 76.387 \\
\hline 7 & 0.0775 & 99.840 & 0.159 & 7 & 0.1250 & 24.680 & 75.319 \\
\hline 8 & 0.0775 & 99.818 & 0.181 & 8 & 0.1321 & 25.458 & 74.541 \\
\hline 9 & 0.0775 & 99.797 & 0.202 & 9 & 0.1383 & 26.047 & 73.952 \\
\hline 10 & 0.0775 & 99.777 & 0.222 & 10 & 0.1439 & $\mathbf{2 6 . 5 0 8}$ & 73.491 \\
\hline
\end{tabular}

\section{Regression analysis}

The values of the correlation coefficient between GDP and energy consumption for V4 countries are shown in Table 14. There are correlation coefficients for two periods.

The following notation is used in the tables in this section of the article: Statistical significance at the 0.01 level $\left({ }^{* *}\right)$, at the 0.05 level $\left({ }^{* *}\right)$, at the 0.1 level $\left(^{*}\right)$.

Table 14. The values of the correlation coefficient (GDP and EC) (source: own calculations, EViews)

\begin{tabular}{|c|c|c|c|c|}
\hline & Czech Republic & Slovakia & Hungary & Poland \\
\hline $2000-2007$ & $0.692^{*}$ & 0.219 & $0.743^{* *}$ & $0.911^{* *}$ \\
\hline $2008-2019$ & -0.024 & -0.085 & 0.489 & $0.898^{* *}$ \\
\hline
\end{tabular}


In the first period from 2000 to 2007 the dependence between GDP and energy consumption has confirmed for the Czech Republic, Hungary and Poland. For the second period from 2008 to 2019 this relationship has confirmed only for Poland. Historically, GDP had a strong relationship with energy consumption, as countries were more oriented towards the manufacturing industry. It is interesting that the correlation coefficient is statistical significant for Poland (for both periods separately) but the co-integration relationship was not proved.

According to regression coefficients we can say, that all regression coefficients are significant for the case of the Czech Republic (Table 15) and Hungary (Table 17). It means

Table 15. Regression analysis for the Czech Republic (dependent variable CZ_GDP) (source: own calculations, EViews)

\begin{tabular}{|l|c|c|c|c|}
\hline & Coefficient & Std.error & t-ratio & Significance \\
\hline$C Z \_E C$ & 156911.9 & 41069 & 3.82 & $0.001^{* * *}$ \\
\hline$C Z \_C P I$ & 74980.5 & 5761.5 & 13.1 & $0.000^{* * *}$ \\
\hline$C Z \_U N E$ & -85637 & 27447.9 & -3.12 & $0.007^{* * *}$ \\
\hline$C$ & -6392094 & 1593098 & -4.01 & $0.001^{* * *}$ \\
\hline
\end{tabular}

Table 16. Regression analysis for Slovakia (dependent variable $S K \_G D P$ ) (source: own calculations, EViews)

\begin{tabular}{|l|c|c|c|c|}
\hline & Coefficient & Std.error & t-ratio & Significance \\
\hline SK_EC & -247.6 & 1262.7 & -0.19 & 0.847 \\
\hline SK_CPI & 1017.8 & 90.5 & 11.25 & $0.000^{* * *}$ \\
\hline SK_UNE & -1304.6 & 267.7 & -4.71 & $0.000^{* *}$ \\
\hline$C$ & -6295.2 & 22587.6 & -0.28 & 0.784 \\
\hline
\end{tabular}

Table 17. Regression analysis for Hungary (dependent variable $H U_{-} G D P$ ) (source: own calculations, EViews)

\begin{tabular}{|l|c|c|c|c|}
\hline & Coefficient & Std.error & t-ratio & Significance \\
\hline$H U \_E C$ & 1517085 & 233696.8 & 6.49 & $0.000^{* * *}$ \\
\hline$H U \_C P I$ & 425169 & 10089.7 & 42.14 & $0.000^{* * *}$ \\
\hline$H U \_U N E$ & -692605 & 85273.14 & -8.12 & $0.000^{* * *}$ \\
\hline$C$ & $-3.10^{7}$ & 4241037 & -6.98 & $0.000^{* * *}$ \\
\hline
\end{tabular}

Table 18. Regression analysis for Poland (dependent variable $P L \_G D P$ ) (source: own calculations, EViews)

\begin{tabular}{|l|c|c|c|c|}
\hline & Coefficient & Std.error & t-ratio & Significance \\
\hline$P L \_E C$ & 19332.6 & 6672.6 & 2.89 & $0.01^{* *}$ \\
\hline$P L \_C P I$ & 26561.6 & 2977.2 & 8.92 & $0.000^{* *}$ \\
\hline$P L \_U N E$ & -9983.9 & 6835.1 & -1.46 & 0.164 \\
\hline$C$ & -2086716 & 467991.6 & -4.46 & $0.000^{* *}$ \\
\hline
\end{tabular}


that variables energy consumption $E C$, rate of inflation $C P I$ and unemployment rate $U N E$ contribute to the explanation of the variable GDP. In the case of Slovakia (Table 16), there was not a significant regression coefficient for variable energy consumption, and in the case of Poland (Table 18), there was not a significant regression coefficient for the variable unemployment rate.

\section{Conclusions}

All V4 countries are part of the European Union and the European Union is an economically strong, politically stable, and technologically one of the most advanced regions of the world. Its high standard of living is made possible mainly by a functioning energy sector. The European Union has set itself three main priorities for energy: reducing import dependency, combating climate change, and increasing competitiveness. The first instrument to address these priorities is to increase efficiency and save energy (lower consumption means lower imports, lower emissions, and lower costs), and the second is to promote renewable resources. As analysing the economic development and energy consumption is a very current topic, there are many relevant studies with different methodologies.

This study has investigated the relationship between aforementioned variables in the Czech Republic, Slovakia, Hungary, and Poland during the period of 2000-2019. Among other things, bivariate models were used in this article. Using these models, a causal relationship was determined: cause and effect. If the cause is energy consumption, then caution must be taken, as this can lead to a reduction in economic growth. To test the stationarity, it was used the ADF test. Variables were zero order co-integrated (Slovakia, Hungary) or first-order co-integrated (the Czech Republic, Poland). For countries the Czech Republic and Poland, it was applied the Johansen co-integration test.

For the Czech Republic, the co-integration relationship was proved and in the next step, it was used the VECM model. A cointegration test was performed and this test proved the existence of a long-term equilibrium relationship between the variables. The results of the VECM model show that in the Czech Republic there is a short-term causal link from energy consumption to economic growth. These findings suggest that it is important not to reduce energy consumption, as this could lead to a reduction in economic prosperity. In the case of Poland, the co-integration relationship was not proved and in the following step, it was used the VAR model. In the case of Slovakia and Hungary, there were used the VAR models. In three countries (Slovakia, Hungary and the Czech Republic), it has been shown that energy consumption could lead to economic growth. The results have been suggesting that energy consumption is a major factor influencing economic growth. In these three countries, energy conservation issues should be addressed with the utmost caution, as these policies may have a negative impact on economic growth. In the case of Slovakia, there is a negative relationship and it means that decreasing the energy consumption leads to the faster increasing GDP. It is a motivation for economic measures. On the other hand, in the case of the Czech Republic and Hungary there are positive relationships between energy consumption and economic development and it means that the economic measures slow down economic growth. Energy conservation may harm economic growth in these countries. In Poland, there is not a significant relationship between energy consumption and economic growth. 
Data for the period 2000-2019 were used for the research. During this period, specifically 2007-2008, the countries were affected by the economic crisis and this fact may be an important factor influencing the research. With the exception of the Czech Republic had deficits of the current account deficit mainly deepened since their entry into the EU (EUROSTAT, 2010). Energy plays a crucial role in socio-economic development, industrial, health, education, employment and overall welfare of a country. A sufficient amount of energy supply, as well as its efficient utilization of the energy, is needed for an economy to completely experience growth and development. Further research in this area could address the analysis of the share of total energy consumption in individual sectors (households, industry, services, transport and agriculture) in V4 during the financial crisis.

The relationship between energy consumption and economic activity is not perfect. Industry is particularly demanding on energy consumption; on the contrary, services require less to create the same added value compared to the energy industry. Both of these sectors were affected during the coronavirus crisis. The measures against the spread of the pandemic themselves are mainly targeted at services - restaurants, accommodation services, shops have been closed, which in turn also affects transport and other related services or industry. The decline in the economy approximated by the decline in energy consumption is thus rather the lower limit of the estimate of the decline in economic activity.

Although the relationship between economic activity and energy consumption is not perfect, its information value is unquestionable. Recent developments (June 2020) have not added much optimism. The decline in energy consumption has increased. We will have to wait for the economy to stabilize. One of the long-term factors that could affect the size of energy consumption is the GDP factor in many studies. Historically, it was this factor that had a strong relationship with energy consumption (this is confirmed by the values of the correlation coefficients), as countries were more oriented towards the manufacturing industry, but today the situation is different.

There may be more reasons why bi-directional causality does not confirm for any country of V4. But the main reason is austerity measures that lead to reduced energy consumption. The austerity measures are divided into groups that combine savings of a similar nature: insulation, energy efficiency, installation of new equipment, lighting, control and regulation, public and non-public transport, etc. However, energy production requires funding that will increase GDP.

This paper deals with the long-run relationship between energy consumption and real GDP for V4 countries from 2005 to 2019. Suggestions for further research: further research can be extended to deals with the short-run relationship between energy consumption and real GDP for V4 countries. Within a short period, it can be investigated whether, for example, the factors of day length, temperature affect energy consumption.

\section{Acknowledgements}

This research was supported by the Ministry of Education, Youth and Sports Czech Republic within the Institutional Support for Long-term Development of a Research Organization in 2020.

\section{Disclosure statement}

The author has no any competing financial, professional, or personal interests from other parties. 


\section{References}

Alvarado, R., Ponce, P., Alvarado, R., Ponce, K., Huachizaca, V., \& Toledo, E. (2019). Sustainable and non-sustainable energy and output in Latin America: A cointegration and causality approach with panel data. Energy Strategy Reviews, 26, 100369. https://doi.org/10.1016/j.esr.2019.100369

Apergis, N., \& Payne, J. (2010). Renewable energy consumption and economic growth: Evidence from a panel of OECD countries. Energy Policy, 38(1), 656-660. https://doi.org/10.1016/j.enpol.2009.09.002

Bašta, M., \& Helman, K. (2013). Scale-specific importance of weather variables for explanation of variations of electricity consumption. The case of Prague, Czech Republic. Energy Economics, 40(C), 503-514. https://doi.org/10.1016/j.eneco.2013.07.023

Bhattacharya, M., Paramati, S., Ozturk, I., \& Bhattacharya, S. (2016). The effect of renewable energy consumption on economic growth: Evidence from top 38 countries. Applied Energy, 162, 733-741. https://doi.org/10.1016/j.apenergy.2015.10.104

Enders, W. (2014). Applied econometric time series. Wiley.

Engle, R. F., \& Granger, C. W. J. (1987). Co-integration and error correction: Representation, estimation, and testing. Econometrica, 55(2), 251-276. https://doi.org/10.2307/1913236

Europa.eu. (2020a). Eurostat database. http://ec.europa.eu/eurostat/data/database

Europa.eu. (2020b). Eurostat database. https://ec.europa.eu/eurostat/statistics-explained/index. php?title=Energy_statistics_-_an_overview\#Energy_dependency

European Commission. (2017). Europe 2020 strategy. https://ec.europa.eu/info/business-economy-euro/ economic-and-fiscal-policy-coordination/eu-economic-governance-monitoring-prevention-correction/european-semester/framework/europe-2020-strategy_en

Eurostat. (2010). Europe in Figures. Brussels: Eurostat Yearbook 2010, Selected economic Indicators. https://ec.europa.eu/eurostat/web/products-statistical-books/-/ks-cd-10-220

Eurostat. (2018a). Gross domestic product (GDP) at market prices. https://ec.europa.eu/eurostat/databrowser/view/TIPSAU10/default/table

Eurostat. (2018b). Energy efficiency. https://appsso.eurostat.ec.europa.eu/nui/show.do?dataset=nrg_ind_ eff\&lang=en

Fisal, Tursoy, T., \& Resatoglu, N. G. (2016). Energy consumption, electricity, and GDP causality; The case of Russia, 1990-2011. Procedia Economics and Finance, 39, 653-659. https://doi.org/10.1016/S2212-5671(16)30312-4

Furuoka, F. (2017). Renewable electricity consumption and economic development: New findings from the Baltic countries. Renewable and Sustainable Energy Reviews, 71, 450-463.

https://doi.org/10.1016/j.rser.2016.12.074

Granger, C. W. J. (1969). Investigating causal relations by econometric models and cross-spectral methods. Econometrica, 37(3), 424-438. https://www.jstor.org/stable/1912791?seq=1\#metadata info_tab_contents

Google. (2020). Public Data. https://www.google.com/publicdata/explore?ds=d5bncppjof8f9_\& met_y=eg_use_pcap_kg_oe\&idim=country:HUN:CZE:POL\&hl=cs\&dl=cs\#!ctype $=1 \&$ strail=false $\& \mathrm{bcs}=\mathrm{d} \&$ nselm $=$ h\&met_y=eg_use_pcap_kg_oe\&scale_y=lin\&ind_y=false\&rdim=world\&idim $=$ country:HUN:POL:SVK:CZE\&ifdim $=$ world \&tstart $=962661600000 \&$ tend $=1435960800000 \& \mathrm{hl}$ $=\mathrm{cs} \& \mathrm{dl}=\mathrm{cs} \&$ ind $=$ false

Hendry, D., \& Juselius, K. (2000). Explaining cointegration analysis: Part I. The Energy Journal, 21(1), 1-42. https://doi.org/10.5547/ISSN0195-6574-EJ-Vol21-No1-1

Hendry, D., \& Juselius, K. (2001). Explaining cointegration analysis: Part II. The Energy Journal, 22(1), 75-120. https://doi.org/10.5547/ISSN0195-6574-EJ-Vol22-No1-4

IHS Global Inc. (2020). EViews 12 [Computer software]. http://www.eviews.com

International Energy Agency. (2018a). Key recommendations. https://www.iea.org/countries/czechrepublic 
International Energy Agency. (2018b). Key recommendations. https://www.iea.org/countries/slovakrepublic

International Energy Agency. (2018c). Key recommendations. https://www.iea.org/countries/poland

International Energy Agency. (2018d). Key recommendations. https://www.iea.org/countries/hungary

Koç, Y., A. \& Bahtiyar, B. (2017). The relationship between energy consumption, economic growth, inflation and trade openness: An analysis for Fragile five countries. International Journal of Research in Business and Social Science (2147-4478), 6(6), 21-41. https://doi.org/10.20525/ijrbs.v6i6.785

Koçak, E., \& Şarkgüneşi, A. (2017). The renewable energy and economic growth nexus in Black Sea and Balkan countries. Energy Policy, 100, 51-57. https://doi.org/10.1016/j.enpol.2016.10.007

Kose, E., Burmaoglu, S., \& Kabak, M. (2013). Grey relational analysis between energy consumption and economic growth. Grey Systems: Theory and Application, 3(3), 291-304. https://doi.org/10.1108/GS-06-2013-0010

Krkošková, R. (2020). Relationship between the brent oil price and the US dollar exchange rate. Prague Economic Papers, 29(2), 187-206. https://doi.org/10.18267/j.pep.718

Li, X., Zhou, D., \& Zhang, H. (2019). Quantitative analysis of energy consumption and economic growth in China. IOP Conference Series: Earth and Environmental Science, 237(4), 042016. https://doi.org/10.1088/1755-1315/237/4/042016

Maji, I. K., Sulaiman, C., \& Abdul-Rahim, A. S. (2019). Renewable energy consumption and economic growth nexus: A fresh evidence from West Africa. Energy Reports, 5, 384-392. https://doi.org/10.1016/j.egyr.2019.03.005

Mutascu, M. (2016). A bootstrap panel Granger causality analysis of energy consumption and economic growth in the G7 countries. Renewable and Sustainable Energy Reviews, 63, 166-171. https://doi.org/10.1016/j.rser.2016.05.055

Nepal, R., \& Paija, N. (2019). Energy security, electricity, population, and economic growth: A case of South Asian developing countries with rich economy resources. Energy Policy, 132, 771-781. https://doi.org/10.1016/j.enpol.2019.05.054

Olopade, B. C., Okodua, H., Oladosun, M., Matthew, O., Urhie, E., Osabohien, R., Adediran, O., \& Johnson, O. H. (2020). Economic growth, energy consumption and human capital formation: Implication for knowledge-based economy. International Journal of Energy Economics and Policy, 10(1), 37-43. https://doi.org/10.32479/ijeep.8165

Ozcan, B., \& Ozturk, I. (2019). Renewable energy consumption-economic growth nexus in emerging countries: A bootstrap panel causality test. Renewable and Sustainable Energy Reviews, 104, 30-37. https://doi.org/10.1016/j.rser.2019.01.020

Ozcicek, O., \& Agpak, F. (2017). The role of education on renewable energy use: Evidence from poisson pseudo maximum likelihood estimations. Journal of Business and Economic Policy, 4(4), 49-61.

Ozturk, I., Adslan, A., \& Kalyoncu, H. (2010). Energy consumption and economic growth relationship: Evidence from panel data for low and middle income countries. Energy Policy, 38(8), 4422-4428. https://doi.org/10.1016/j.enpol.2010.03.071

Pampuri, L., Cereghetti, N., Strepparava, D., \& Caputo, P. (2016). Analysis of the electricity consumptions: A first step to develop a district cooling system. Sustainable Cities and Society, 23, 23-36. https://doi.org/10.1016/j.scs.2016.02.015

Pao, H., Li, Y., \& Fu, H. C. (2014). Causality relationship between energy consumption and economic growth in Brazil. Smart Grid and Renewable Energy, 5(8), 198-205. https://doi.org/10.4236/sgre.2014.58019

Pao, H. T., \& Fu, H. C. (2013). Renewable energy, non-renewable energy and economic growth in Brazil. Renewable and Sustainable Energy Reviews, 25, 381-392. https://doi.org/10.1016/j.rser.2013.05.004

Payne, J. E. (2010). A survey of the electricity consumption-growth literature. Applied Energy, 87(3), 723-731. https://doi.org/10.1016/j.apenergy.2009.06.034 
Popescu, G. H., Andrei, J. V., Nica, E., Mieilă, M., \& Panait, M. (2019). Analysis on the impact of investments, energy use and domestic material consumption in changing the Romanian economic paradigm. Technological and Economic Development of Economy, 25(1), 59-81. https://doi.org/10.3846/tede.2019.7454

Rafindadi, A. A., \& Ozturk, I. (2017). Impacts of renewable energy consumption on the German economic growth: Evidence from combined cointegration test. Renewable and Sustainable Energy Reviews, 75, 1130-1141. https://doi.org/10.1016/j.rser.2016.11.093

Rahman, M. M., \& Velayutham, E. (2020). Renewable and non-renewable energy consumption-economic growth nexus: New evidence from South Asia. Renewable Energy, 147, 399-408. https://doi.org/10.1016/j.renene.2019.09.007

Saad, W., \& Taleb, A. (2018). The causal relationship between renewable energy consumption and economic growth: Evidence from Europe. Clean Technologies and Environmental Policy, 20(1), 127-136. https://doi.org/10.1007/s10098-017-1463-5

Shahid, A. U., Rathore, M., Aslam, N., \& Tariq, M. I. (2014). An empirical analysis of energy consumption and economic growth in Brazil. Journal of Economics and Development Studies, 2(2), 591-599.

Shin, J., Yang, H., \& Kim, C. (2019). The relationship between climate and energy consumption: The case of South Korea. Energy Sources, Part A: Recovery, Utilization, and Environmental Effects. https://doi.org/10.1080/15567036.2019.1673853

Soava, G., Mehedintu, A., \& Sterpu, M. (2020). Relations between income inequality, economic growth and poverty threshold: new evidences from EU countries panels. Technological and Economic Development of Economy, 26(2), 290-310. https://doi.org/10.3846/tede.2019.11335

Soava, G., Mehedintu, A., Sterpu, M., \& Raduteanu, M. (2018). Impact of renewable energy consumption on economic growth: Evidence from European Union countries. Technological and Economic Development of Economy, 24(3), 914-932. https://doi.org/10.3846/tede.2018.1426

Szép, T. S. (2014). The Granger causality analysis of energy consumption and economic growth. Marketing and Management of Innovations, 1, 244-258. https://www.researchgate.net/publication/272149473_The_granger_causality_analysis_of_energy_consumption_and_economic_growth

Tang, C. F., \& Ozturk, I. (2016). Energy consumption and economic growth in Vietnam. Renewable and Sustainable Energy Reviews, 54, 1506-1514. https://doi.org/10.1016/j.rser.2015.10.083

Tugcu, C. T., Ozlturk, I., \& Aslain, A. (2012). Renewable and non-renewable energy consumption and economic growth revisited: Evidence from G7 countries. Energy Economics, 34(6), 1942-1950. https://doi.org/10.1016/j.eneco.2012.08.021

Visegrad Declaration. (1991). The Visegrad Group: the Czech Republic, Hungary, Poland and Slovakia. http://www.visegradgroup.eu/main.php?folderID=940\&articleID=3940\&ctag=articlelist\&iid=1

Wada, I. (2017). Energy production and economic growth in Saudi Arabia: Dynamic causality. Energy Sources, Part B: Economics, Planning and Policy, 12(6), 584-590. https://doi.org/10.1080/15567249.2016.1248872

Wiranata, D. B., \& Muqorrobin, M. (2013). The relationship between energy consumption and economic growth. Trikonomika, 12(2), 103-112. https://doi.org/10.23969/trikonomika.v12i2.470

Yildirim, E., Sarac, S., \& Aslan, A. (2012). Energy consumption and economic growth in the USA: Evidence from renewable energy. Renewable and Sustainable Energy Review, 16(9), 6770-6774. https://doi.org/10.1016/j.rser.2012.09.004

Zafar, M. W., Shahbaz, M., Hou, F., \& Sinha, A. (2019). From nonrenewable to renewable energy and its impact on economic growth: The role of research \& development expenditures in Asia-Pacific Economic Cooperation countries. Journal of Cleaner Production, 212, 1166-1178.

https://doi.org/10.1016/j.jclepro.2018.12.081 